\title{
Performance of Broilers Fed During 21 Days on Mash or Pellet Diets Containing Whole or Ground Pearl Millet Grain
}

\section{mAuthor(s)}

Torres TR

Ludke M do CM M"

Ludke JVIII

Santos MJB dos'

MR Limal

Santos PA dos'

Animal Scientist, PhD student in Animal Science, UFRPE, thaysatorres@hotmail. com, Recife, PE.

" Animal Scientist, Associate Professor, Departmentof Animal Science, UFRPE, Recife, PE.

III Researcher, EMBRAPA Suínos e Aves, Concordia, SC

\section{ABSTRACT}

An experiment was carried out to evaluate the effect of the inclusion of $20 \%$ whole-grain or ground pearl millet (PM) in mash and pelleted diets on the performance, carcass traits, and organ weights of broilers reared until 21 days of age. A randomized block experimental design in a $3 \times 2$ factorial arrangement (diets containing corn and soybean meal, whole-grain PM, or ground PM x mash or pelleted diets), with five replicates per treatment and 10 birds per experimental unit, was applied. Diets were analyzed for mean geometric diameter, geometric standard deviation, pellet hardness, and density. Broiler performance, carcass yield, and organ weights were evaluated. On day 21, one bird with the average weight of each experimental unit was sacrificed for carcass evaluation. It was concluded that both as whole-grain and ground PM can be added to the diet of broilers up to 21 days of age. The dietary inclusion of PM results in higher abdominal fat deposition. Broilers fed the pelleted diets presented lower feed intake, better feed conversion ratio, lower gizzard and heart percentages, and higher carcass weight.

\section{INTRODUCTION}

The high cost of broiler feeds has stimulated an increasing demand for alternative feed stuffs, including pearl millet (Pennisetumamericanum L. Leeke), which is cultivated for different purposes in four million hectares in Brazil annually. In the Midwestern region of Brazil, it is planted in the spring using a no-tillage system as a cover crop to supply nutrients for the next summer crop or during the second harvest for soil cover, nutrient cycling, and grain production (Netto \& Durães, 2005). The surplus of grains harvested for seed and not used for planting is sold as feedstuff, at $60-75 \%$ of the average corn price.

Pearl millet (PM) has higher protein content, but lower apparent metabolizable energy (AMEn) than corn for broilers (Rostagno et al., 2011). However, according to Murakami et al. (2009), the AMEn of modern PM hybrids is very similar to that of corn. Pearl millet can be added at $40 \%$ to pre-starter and starter iso-nutrient broiler diets (Gomes et al., 2008) with no harm to their performance. Davis et al. (2003) concluded that it was feasible to include 50\% PM in iso-nutrient diets, and Murakami et al. (2009) asserted that it is profitable to replace $100 \%$ corn by PM in the diets of broilers of all phases. According to Baurhoo et al. (2011), broiler performance was superior when corn was completely replaced by PM in diets. On the other hand, with complete and isometric replacement of corn by different millet types, Rao et al. (2004) described worse weight gain and feed conversion ratio of 21and 42-d-old broilers. 
Different PM cultivars present different productivity, nutritional composition, and grain texture (Hadimani et al., 2001). Grain texture determines the effectiveness of grinding, affecting mill energy use and profitability. Dozier et al. (2005) observed that energy expenditure (in $\mathrm{kWh} /$ ton) increases in $30 \%$ when PM is ground to 2.4-mm mesh, resulting in a mean geometric diameter (MGD) of $492 \mu \mathrm{m}$, compared with the use of 3.2-mm mesh, producing a particles with 611- $\mu \mathrm{m}$ Dgw. Fine grinding increases the temperature of the ground fraction in $3.4^{\circ} \mathrm{C}$. Considering the results of those authors, the energy required for grinding and pelleting was reduced in 19\% when manufacturing pelleted diets containing 50\% PM ground finer. However, according to Hidalgo et al. (2004), the use of whole-grain PM at $10 \%$ inclusion level in nutritionally balanced diets does not affect broiler performance or pellet quality.

The objective of the present study was to evaluate the performance, carcass traits, and organ weights of broilers fed mash or pelleted diets containing 20\% whole-grain or ground PM until 21 days of age.

\section{MATERIALS AND METHODS}

Three hundred one-d-old male Ross chicks were distributed, according to body weight, in 30 identical pens $(1.00 \mathrm{~m} \times 1.95 \mathrm{~m})$ inside a poultry house. A randomized block experimental design in a $3 \times 2$ factorial arrangement was applied. Treatments consisted of three nutritionally balanced diets [a reference diet based on corn and soybeans (RD), a diet with 20\% whole-grain millet, and a diet with 20\% ground millet (GM)] and two physical forms [mash (MASH) or pelleted (PELL)]. There were five replicates per treatment. Birds were vaccinated in the hatchery against Marek's disease, infectious bursal disease (IBD), and Newcastle disease, and were revaccinated against IBD and Newcastle disease in the poultry house at seven days of age.

Feeds were manufactured with ground feedstuffs in a hammer mill with a $2.00-\mathrm{mm}$ mesh. During pelleting, water was heated to $80^{\circ} \mathrm{C}$ at a ratio of $30 \%$ water and $70 \%$ mash in the conditioner. This homogenized material was then transferred to the pelleting press. The pelleted feed was placed on trays lined with newspaper and dried in a forced-ventilation oven at $55^{\circ} \mathrm{C}$ for 16 hours. After pelleting, pre-starter diets were crumbled in a crumbler with a 2-mm mesh, and the starter diets were manually broken to achieve a diameter that allowed their ingestion by the birds.
The pre-starter diet was fed from one to seven days of age and the starter diet from eight to 21 days of age. Feed formulation was based on digestible amino acid, considering the requirements proposed by Rostagno et al. (2005), as shown in Table 1. Feed samples were collected after manufacturing to determine diet physical characteristics and for routine chemical analyses. Pellet hardness was determined according to the methodology described by Schmidt et al. (2009). Feed apparent density was determined by pouring the sample into a test tube placed on a precision scale in order to prevent sample compaction, and the mass (weight) was recorded and expressed in $\mathrm{g} / \mathrm{L}$.

Table 1 - Ingredients and calculated composition of the prestarter (1-7 days) and starter (8-21 days) experimental diets.

\begin{tabular}{|c|c|c|c|c|}
\hline \multirow[b]{2}{*}{ Ingredients } & \multicolumn{2}{|c|}{ Pre-starter } & \multicolumn{2}{|c|}{ Starter } \\
\hline & $\begin{array}{c}\text { No } \\
\text { millet }\end{array}$ & $\begin{array}{l}\text { With } \\
\text { millet }\end{array}$ & $\begin{array}{c}\text { No } \\
\text { millet }\end{array}$ & $\begin{array}{l}\text { With } \\
\text { millet }\end{array}$ \\
\hline Corn grain & 53.148 & 35.065 & 55.159 & 37.100 \\
\hline Soybeanmeal & 38.106 & 35.061 & 36.262 & 33.200 \\
\hline Millet & 0.000 & 20.000 & 0.000 & 20.000 \\
\hline Soybeanoil & 3.464 & 4.501 & 3.870 & 4.920 \\
\hline Dicalcium phosphate & 1.945 & 1.967 & 1.840 & 1.854 \\
\hline Calcitic limestone & 0.938 & 0.942 & 0.880 & 0.880 \\
\hline Salt & 0.518 & 0.524 & 0.500 & 0.500 \\
\hline Vitamin and mineral premix ${ }^{1}$ & 0.200 & 0.200 & 0.200 & 0.200 \\
\hline L-Lysine HCL (78\%) & 0.363 & 0.418 & 0.193 & 0.240 \\
\hline DL-Methionine (99\%) & 0.384 & 0.384 & 0.270 & 0.270 \\
\hline L-threonine 99\% & 0.167 & 0.173 & 0.060 & 0.070 \\
\hline Adsorbent ${ }^{2}$ & 0.500 & 0.500 & 0.500 & 0.500 \\
\hline Cholinechloride $60 \%$ & 0.100 & 0.100 & 0.100 & 0.100 \\
\hline Antifungal agent ${ }^{3}$ & 0.100 & 0.100 & 0.100 & 0.100 \\
\hline Zinc bacitracin $(10 \%)$ & 0.050 & 0.050 & 0.050 & 0.050 \\
\hline Antioxidant $(\mathrm{BHT})^{4}$ & 0.010 & 0.010 & 0.010 & 0.010 \\
\hline Binder $^{5}$ & 0.006 & 0.006 & 0.006 & 0.006 \\
\hline \multicolumn{5}{|l|}{ Calculated composition } \\
\hline Metabolizable energy (kcal/kg) & 3000 & 3000 & 3050 & 3050 \\
\hline Crude protein, \% & 22.11 & 22.11 & 21.14 & 21.14 \\
\hline Calcium, \% & 0.950 & 0.950 & 0.900 & 0.900 \\
\hline Available phosphorus, \% & 0.471 & 0.471 & 0.450 & 0.450 \\
\hline Digestible lysine, \% & 1.363 & 1.363 & 1.189 & 1.189 \\
\hline Digestible methionine + cystine (\%) & 0.968 & 0.968 & 0.844 & 0.844 \\
\hline Digestiblephenylalanine + tyrosine, $\%$ & 1.682 & 1.634 & 1.628 & 1.580 \\
\hline Digestible isoleucine, \% & 0.863 & 0.889 & 0.833 & 0.859 \\
\hline Digestible leucine, \% & 1.709 & 1.692 & 1.669 & 1.652 \\
\hline Digestible threonine (\%) & 0.886 & 0.886 & 0.773 & 0.773 \\
\hline Digestible tryptophan (\%) & 0.245 & 0.247 & 0.236 & 0.238 \\
\hline
\end{tabular}

'Guaranteed levels per kg product:vit. A (10,000,000IU), vit. D3 (2,000,000IU), vit. E (20,000mg), vit. K3 (4,000mg), vit. B1 (1880mg), vit. B2 (5000mg), vit. B6 (2000mg), vit. B12 (10,000 mcg), Niacin (30,000mg), Pantothenic Acid (13,500mg), Folic Acid (500 mg), Selenium (360mg), Zinc (110,000mg), lodine (1400mg), Copper (20,000mg), Manganese (156 $000 \mathrm{mg})$, Iron (96.000mg), Antioxidant (100.000mg), QSP vehicle $1000 \mathrm{~g}$. ${ }^{2}$ Adsorbent Azomite. ${ }^{3}$ Calcium propionate. ${ }^{4}$ Butylated hydroxy toluene, ${ }^{5}$ Sodium Alginate. 
Particle size was determined as described by the ANSI/ASAE Standards (2008), aiming at calculating Dgw and geometric standard deviation (Sgw) of the experimental feeds. Calculations were performed using the software program Softgran, version 2.0, developed by Embrapa Suínos e Aves (2011).

The duration of the experiment was 21 days, and water and feed were supplied ad libitum. Birds and feed residues in each experimental unit were weekly weighed, and mortality, when present, was recorded. Weight gain, feed intake, feed conversion ratio, and energy and protein efficiencies for weight gain were calculated for the pre-starter and starter phases.

On day 21, birds were weighed, andtwo birds per experimental unit, which body weight was close to the average weight of each pen, were selected. These birds were feed fasted for six hours, and then sacrificed by neck dislocation. Carcasses were then bled, scalded, plucked, and eviscerated. Hot carcasses and organs were weighed. Heart, gizzard, liver, pancreas and the small and large intestines were collected. Gizzards were opened and rinsed with water to remove their feed content, and were again weighed (empty gizzard weight) after fat removal. Total carcass fat was determined as the sum of abdominal fat, gizzard fat, and the fat around the ischium, surrounding the bursa of Fabricius, cloaca, and adjacent abdominal muscles. Digestive organ percentage was calculated as the ratio between organ weight and fasting live weight. The main parts were cut, and carcass yield and parts (breast, leg (drumstick+thigh), and wing) yields were determined. Carcass yield was determined as the ratio between carcass weight and fasting live weight, and parts yield were calculated as the ratio between parts weight and cold carcass weight.

Data homoscedasticity was analyzed by the test of Bartlett. Data were then submitted to analysis of variance using the statistical package Statistical Analysis Systems (SAS, 2000). Means were compared by the test of Tukey at $5 \%$ probability level.

Table 2 - Effect of diet formulation and physical form on average feed intake (Fl, g/bird), weight gain (WG, g/bird), feed conversion ratio $(F C R, g / g)$, energy efficiency $(E E, k c a l / g)$, and protein efficiency $(P E, g / g)$ during the pre-starter (1-7 days) and starter (8-21 days) and total experimental period.

\begin{tabular}{|c|c|c|c|c|c|c|c|c|c|}
\hline \multirow{2}{*}{ Parameters } & \multicolumn{3}{|c|}{ Diets (D) } & \multirow{2}{*}{$p$ value } & \multicolumn{2}{|c|}{ Physical form } & \multirow{2}{*}{$p$ value } & \multirow{2}{*}{$\begin{array}{l}C V \\
(\%)\end{array}$} & \multirow{2}{*}{$D \times P F$} \\
\hline & WGM & GM & $\mathrm{RD}$ & & MASH & PELL & & & \\
\hline \multicolumn{10}{|c|}{ Pre-starter phase (1-7 days) } \\
\hline $\mathrm{Fl}, \mathrm{g} / \mathrm{bird}$ & 148.4 & 150.6 & 146.1 & 0.2814 & $152.7^{\mathrm{a}}$ & $144.0^{b}$ & 0.0023 & 4.46 & 0.5862 \\
\hline WG, g/bird & 148.0 & 150.0 & 149.3 & 0.7747 & 146.8 & 151.4 & 0.0549 & 4.24 & 0.0461 \\
\hline$F C R, g / g$ & $1.01^{\mathrm{a}}$ & $1.00^{\mathrm{ab}}$ & $0.98^{b}$ & 0.0248 & $1.04^{\mathrm{a}}$ & $0.95^{b}$ & 0.0001 & 2.12 & 0.0031 \\
\hline $\mathrm{EE}, \mathrm{kcal} / \mathrm{g}$ & $0.335^{\mathrm{ab}}$ & $0.331^{b}$ & $0.341^{\mathrm{a}}$ & 0.0372 & $0.320^{b}$ & $0.351^{\mathrm{a}}$ & 0.0001 & 2.58 & 0.0185 \\
\hline$P E, g / g$ & $4.52^{b}$ & $4.51^{\mathrm{b}}$ & $4.63^{\mathrm{a}}$ & 0.0153 & $4.35^{\mathrm{b}}$ & $4.76^{a}$ & 0.0001 & 2.16 & 0.0052 \\
\hline \multicolumn{10}{|c|}{ Starter phase (8-21 days) } \\
\hline Fl, g/bird & $988.4^{\mathrm{a}}$ & $947.1^{\mathrm{b}}$ & $959.9^{a b}$ & 0.0489 & $985.9^{a}$ & $944.3^{b}$ & 0.0046 & 3.57 & 0.2925 \\
\hline WG, g/bird & 766.1 & 744.0 & 749.7 & 0.2861 & 743.4 & 763.2 & 0.0951 & 4.10 & 0.1161 \\
\hline$F C R, g / g$ & 1.29 & 1.27 & 1.28 & 0.6975 & $1.33^{\mathrm{a}}$ & $1.24^{b}$ & 0.0001 & 2.62 & 0.4120 \\
\hline $\mathrm{EE}, \mathrm{kcal} / \mathrm{g}$ & $0.224^{b}$ & $0.234^{\mathrm{a}}$ & $0.230^{\mathrm{ab}}$ & 0.0043 & $0.219^{b}$ & $0.239^{a}$ & 0.0001 & 2.40 & 0.0407 \\
\hline$P E, g / g$ & 3.67 & 3.72 & 3.70 & 0.5698 & $3.57^{b}$ & $3.82^{\mathrm{a}}$ & 0.0001 & 2.64 & 0.3619 \\
\hline \multicolumn{10}{|c|}{ Total period (1-21 days) } \\
\hline $\mathrm{Fl}, \mathrm{g} / \mathrm{bird}$ & 1166.5 & 1128.0 & 1137.0 & 0.0771 & $1170.4^{\mathrm{a}}$ & $1117.0^{\mathrm{b}}$ & 0.0010 & 3.18 & 0.3068 \\
\hline WG, g/bird & 914.0 & 893.2 & 892.8 & 0.3707 & 886.0 & 914.1 & 0.0569 & 4.21 & 0.0805 \\
\hline$F C R, g / g$ & 1.24 & 1.22 & 1.22 & 0.3405 & $1.27^{\mathrm{a}}$ & $1.18^{b}$ & 0.0001 & 2.13 & 0.2089 \\
\hline
\end{tabular}

$a-b$ - Means in the same row followed by different lowercase letters are significantly different $(p<0.05)$; $P$ - probability; CV - coefficient of variation; D x PF - interaction between diet formulation and physical form. 


\section{RESULTS AND DISCUSSION}

There was no effect of treatments on feed intake in the pre-starter phase, on feed conversion ratio and protein efficiency in the starter phase, or on weight gain in both evaluated phases (Table 2). Considering the total experimental period of 21 days, there were no weight gain, feed intake, or feed conversion ratio differences among broilers fed the treatment diets. Davies et al. (2003), feeding up to $66 \%$ ground PM to broilers, found that the performance and carcass yield of broilers fed up to 55\% PM was equivalent or better than of those fed a typical corn- and soybean mealbased diet. Hidalgo et al. (2004) included up to $20 \%$ whole-grain PM in the diet and evaluated its digestion, measured by the presence of whole grains in the excreta at 14 days of age. It was determined that $98.5 \%$ of the whole grains were readily digested, and there were no differences in digestibility values among diets.

In the present experiment, diet physical form (MASH or PELL) influenced feed intake. Feed intake of the broilers fed the mash feeds was 6 and $4 \%$ higher compared with those fed the pelleted feeds during the pre-starter and the starter phases, respectively. These results are different from those reported by Dalke et al. (2001), who evaluated mash and pelleted feeds with the same particle size. They found that broilers fed mash or pelleted diets presented the same feed intake. Energy expenditure to consume pelleted feeds is lower than that needed to consume finely-ground feeds. According to Klasing (2000), poultry prefer to eat particles with an oval shape as they are easier to grasp, and therefore less time is required to feed. Hence, feed intake regulation depends on diet physical form, as poultry prefer large particles instead of finelyground meals (Moran, 1987).

The use of pelleted feed promoted better weight gain, feed conversion ratio, and energy and protein efficiency compared with mash diets in both evaluated phases. Larger particles usually result in longer transit time due to the longer retention time of the feed in the gizzard (Carré, 2004). This author mentions that literature data suggest that coarse grinding also reduces water excretion and often improve protein digestibility due to better control of intestinal transit via gastric emptying. Nagano et al. (2003) also obtained better average body weight and feed conversion ratio in 7-d-old broilers fed pelleted and extruded feeds compared with those fed mash feeds.

The interaction between diet formulation and physical form influenced weight gain, feed conversion ratio, and both energy and protein efficiency of the broilers in the pre-starter, but only energy efficiency in the starter phase (Table 3).

Table 3 - Details of the influence of the interaction between diet composition and physical form on studied parameters.

\begin{tabular}{|c|c|c|}
\hline \multirow{2}{*}{ Diets } & \multicolumn{2}{|c|}{ Physical form } \\
\hline & Mash & Pelleted \\
\hline \multicolumn{3}{|c|}{ Feed conversion ratio (1-7 days of age), g/g } \\
\hline Whole-grain millet feed & $1.07^{\mathrm{a}}$ & $0.94^{b}$ \\
\hline Ground millet feed & $1.03^{a}$ & $0.98^{b}$ \\
\hline Reference diet & $1.03^{\mathrm{a}}$ & $0.94^{b}$ \\
\hline \multicolumn{3}{|c|}{ Individual weight gain (1-7 days of age), g } \\
\hline Whole-grain millet feed & $141.53^{b}$ & $154.53^{\circ}$ \\
\hline Ground millet feed & 151.08 & \\
\hline Reference diet & 147.8 & $\begin{array}{l}148.92 \\
150.79\end{array}$ \\
\hline \multicolumn{3}{|c|}{ Energy efficiency (1-7 days of age), kcal/g } \\
\hline Whole-grain millet feed & $0.314^{b}$ & $0.356^{a}$ \\
\hline Ground millet feed & $0.322^{\mathrm{b}}$ & $0.340^{\mathrm{a}}$ \\
\hline Reference diet & $0.323^{b}$ & $0.359^{\mathrm{a}}$ \\
\hline \multicolumn{3}{|c|}{ Protein efficiency (1-7 days of age), $\mathrm{g} / \mathrm{g}$} \\
\hline Whole-grain millet feed & $4.24^{b}$ & $4.80^{\mathrm{ABa}}$ \\
\hline Ground millet feed & $4.40^{\mathrm{b}}$ & $4.62^{\mathrm{Ba}}$ \\
\hline Reference diet & $4.40^{\mathrm{b}}$ & $4.86^{\mathrm{Aa}}$ \\
\hline \multicolumn{3}{|c|}{ Energy efficiency (8-21 days of age), kcal/g } \\
\hline Whole-grain millet feed & $0.218^{b}$ & $0.230^{\text {Ba }}$ \\
\hline Ground millet feed & $0.222^{b}$ & $0.245^{\mathrm{Aa}}$ \\
\hline Reference diet & $0.218^{b}$ & $0.242^{\mathrm{Aa}}$ \\
\hline
\end{tabular}

$a-b$ and A-B:Means followed by different lowercase letters in the same row and uppercase letters in the same column are significantly different $(p<0.05)$.

The details of the interaction show a negative effect of the inclusion of whole-grain PM on the performance of chicks fed the mash diet. During the pre-starter phase, chicks were heavier when the diet containing whole-grain PM was pelleted. Energy efficiency was better when birds were fed the pelleted diets in all evaluated phases. However, differences among pelleted diets were observed, with lower energy efficiency when whole-grain PM was added. During the pre-starter phase, the calculated protein efficiency of chicks fed the pelleted diet was affected by diet formulation. Those fed ground PM presented lower protein efficiency values compared with those fed pelleted the corn and soybean meal diet (RD), whereas similar values were obtained in those fed GM and RD in the mash form. During the pre-starter phase, weight gain was lower in the chicks fed the mash diet containing WGM, but there was no difference among those fed the pelleted diets, probably because the pelleting process reduced the selection of millet grains in the mash diet. Moreover, the use of energy and protein depends on the physical form of the consumed grain, and pellets may reduce ingestion time (Moran, 1987) and energy spent for food apprehension (Flemming et al., 2002). 
Some of the observed interactions between diet formulation and physical form may be attributed to the physical characteristics of the diets. Pellet hardness values determined for the starter diets were 87, 86, and $86.4 \%$ for the WGM (whole-grain millet), GM (ground millet), and RD (reference diet), respectively. These values are higher than those described by Dozier et al. (2005), who evaluated pelleted diets containing three different PM particle sizes and two PM inclusion levels. According to Moran (1987), the hardness of good-quality pellets is $87 \%$, whereas low-quality pellets present $23 \%$ hardness. Hidalgo et al. (2004) obtained a pellet hardness of $89 \%$ when including 10\% PM in a starter diet. The values calculated in the present study are consistent with those published by Parsons et al. (2006), who used corn with a Dgw of $491 \mu \mathrm{m}$. Nevertheless, pellet hardness depends on multiple and interdependent factors, such as processing temperature, feedstuff type, mill type and grinding degree, additive use, differences in the evaluation methods, etc.

During the pre-starter phase, the density of the mash diets (in $\mathrm{g} / \mathrm{L}$ ) was835, 846, and 845 for WGM, $\mathrm{GM}$, and RD, respectively. The pelleted diets presented densities of 880, 920, and 910 for WGM, GM, and RD, respectively. Similar results were obtained for the starter phase, with mash diet density values of 880, 890, and 870 for WGM, GM, and RD, respectively, and 920, 915, and 935 for pelleted WGM, GM, and RD, respectively. The density values determined for the pelleted diets are higher than those described by Parsons et al. (2006), who used finely-ground corn. The pelleted/crumbled diets in the pre-starter phase and the pelleted diets in the starter phase presented higher density than the mash diets. This result was expected, because pelleting changes particle texture or size, the attraction force among particles, and the number of contact points, as well as anti-agglomerating agents, affecting diet density, as mentioned by Passos Jr. \& Bose (2002).

The pelleted/crumbled diets fed in the pre-starter phase presented Dgw (in $\mu \mathrm{m}$ ) of1029, 935 and 880 for the RD, WGM, and GM diets, respectively, withan associated Sgw of 2.28, 2.10, and 2.05, in the same order. Sgw represents the degree of lack of uniformity among feed particles. According to Nir et al. (1994), broilers fed low-Sgw diets presented better weight gain and feed conversion ratio compared with those fed diets with higher Sgw. However, this depends on the type of cereal (corn, sorghum, wheat, or millet) in the diet, and therefore, different results are expected particularly because for the same type of mill and mesh, different cereals present similar Dgw, but their Sgw may be highly variable. The mash pre-starter diet presented Dgw values (in $\mu \mathrm{m}$ ) of 736, 854 and 682 for the RD, WGM, and GM diets, respectively, withan associated Sgw of 1.83, 1.88, and 1.80. Flemming et al. (2002) compared mash pre-starter diets based on corn and soybean meal, with Dgw between 703 and $1058 \mu \mathrm{m}$, and obtained lower feed intake and weight gain in broilers fed the diet with the highest Dgw. However, there was no effect on broiler performance in the starter, grower, or finisher phases. This shows that, for broilers, the particle size of the mash diet affects their performance during the pre-starter phase. The pelleted/crumbled diets fed in the starter phase presented Dgw values (in $\mu \mathrm{m}$ ) of 2735, 2556, and 2535 for RD, WGM, and GM, respectively, with associated Sgw, in the same order of 1.87, 1.76, and 1.97. The mash starter diets presented Dgw values (in $\mu \mathrm{m}$ ) of 817, 881, and 724 for RD, WGM, and GM, respectively, with associated Sgw values, in the same order of 1.65, 1.89, and 1.68. In the pre-starter phase, independently of diet physical form, Dgw and Sgw were strongly and positively correlated (Table 4).

Table 4 - Values of the correlation between diet physical form and performance parameters in the pre-starter phase, when the interaction between diet formulation and physical form was significant.

\begin{tabular}{|c|c|c|c|c|c|c|c|c|}
\hline \multicolumn{9}{|c|}{ Mash diets } \\
\hline & Dens $^{1}$ & Dgw & Sgw & FCR & WG & $\mathrm{EE}$ & PE & $\mathrm{Fl}$ \\
\hline Dens & - & 0.129 & 0.061 & 0.427 & -0.096 & -0.517 & -0.427 & 0.412 \\
\hline Dgw & 0.609 & - & 0.998 & 0.952 & -0.999 & -0.916 & -0.952 & -0.850 \\
\hline Sgw & 0.470 & 0.986 & - & 0.929 & -0.999 & -0.886 & -0.929 & -0.884 \\
\hline FCR & -0.971 & -0.782 & -0.668 & - & -0.941 & -0.994 & -0.999 & -0.648 \\
\hline WG & 0.891 & 0.182 & 0.018 & -0.756 & - & 0.902 & 0.941 & 0.867 \\
\hline $\mathrm{EE}$ & 0.925 & 0.865 & 0.770 & -0.989 & 0.652 & - & 0.995 & 0.567 \\
\hline PE & 0.885 & 0.909 & 0.827 & -0.971 & 0.577 & 0.995 & - & 0.648 \\
\hline $\mathrm{FI}$ & -0.420 & -0.976 & -0.998 & 0.626 & 0.038 & -0.733 & 0.795 & - \\
\hline
\end{tabular}

Pelleted/crumbled diets

'Dens - diet density, Dgw - geometric mean diameter, Sgw - geometric standard deviation, FCR - feed conversion ratio (g/g), WG - weight gain (g), EE - energy efficiency (kcal/g) and PE - protein efficiency $(\mathrm{g} / \mathrm{g})$, Fl - feed intake $(\mathrm{g})$ 
In the pre-starter phase, the density of the mash diets did not present any significant correlation with the evaluated performance parameters. However, in the Dgw range between $682 \mu \mathrm{m}$ (GM diet) and 854 $\mu \mathrm{m}$ (WGM diet), there was an inverse relation between Dgw and performance. For instance, feed conversion ratio increased with Dgw, i.e., higher Dgw values worsened feed conversion ratio. On the other hand, the density of pelleted diets was positively correlated with weight gain, energy efficiency, and protein efficiency, and inversely correlated with feed conversion ratio (higher density promoted better feed conversion ratio).

In the pre-starter phase, the Dgw values of the pelleted diets was positively correlated only with energy and protein efficiencies, and negatively correlated with feed intake. The Sgw values followed the same trend. The higher the Dgw (and Sgw) values, the lower the feed intake, and due to a subtle feed restriction, energy and protein efficiencies improved.

During the starter phase, the density of the mash diets was negatively correlated with Dgw and Sgw values, and positively correlated with energy efficiency (Table 5). However, in the pelleted diets, density was positively correlated only with Dgw, and there was no significant correlation between Dgw and Sgw; however, Sgw was positively correlated with energy efficiency. This is an indirect effect of the marginal reduction in feed intake caused by higher Sgw values, as observed in the GM and RD diets. The absence of correlation between Dgw and Sgw in pelleted diets is due to the fact that pellets were manually crumbled to obtain the adequate diameter to allow diet ingestion by chicks between eight and 21 days of age.
Table 5 - Values of the correlation between diet physical characteristics and energy efficiency during the starter phase.

\begin{tabular}{lcccc}
\hline \multicolumn{5}{c}{ Mash diet } \\
\hline & Density & Dgw $^{1}$ & Sgw & Energy efficiency \\
\hline Density & - & -0.994 & -0.803 & 0.866 \\
\hline Dgw & 0.943 & - & 0.735 & -0.914 \\
\hline Sgw & 0.267 & -0.068 & - & -0.397 \\
\hline Energy efficiency & 0.545 & 0.236 & 0.954 & - \\
\hline Pelleted diet & & & & \\
\hline
\end{tabular}

'Dgw - geometric mean diameter, Sgw - geometric standard deviation

The evaluated diets did not influence carcass yield or parts yield (Table 6). However, carcass weight was significantly affected by diet physical form, with heavier carcasses obtained from broilers fed pelleted diets.

The interaction between diet formulation and physical form affected carcass weight, but no significant differences were detected when the interaction was detailed. Davis et al. (2003) evaluate different millet levels fed to broilers until 42 days of age and found that the inclusion of up to $50 \%$ PM in pelleted diets did not affect carcass yield.

Absolute and relative heart, liver, intestine, lung, spleen, and gizzard weights were not affected by diet formulation (Table 7). Hidalgo et al.(2004) using whole-grain PM in mash diets reported an increase in gizzard relative weight when PM levels of $10 \%$ or higher were included in the diet of 15 -d-old broilers. However, gizzard weight was affected by diet physical form, promoting higher weight and yield in the broilers fed mash relative to pelleted diets. The mash diet may have stimulated gizzard function, resulting in the expressive muscle development observed. Engberg

Table 6 - Average carcass weight, carcass yield, and parts yield of 21-d-old broilers as a function of diet formulation and physical form.

\begin{tabular}{|c|c|c|c|c|c|c|c|c|c|}
\hline \multirow{2}{*}{ Parameters } & \multicolumn{3}{|c|}{ Diets (D) } & \multirow{2}{*}{$p$ value } & \multicolumn{2}{|c|}{ Physical form (PF) } & \multirow{2}{*}{$p$ value } & \multirow{2}{*}{$\begin{array}{l}C V \\
(\%)\end{array}$} & \multirow{2}{*}{$\frac{p \text { value }}{D \times P F}$} \\
\hline & WGM & GM & $\mathrm{RD}$ & & MASH & PELL & & & \\
\hline Carcass weight, g & 726.4 & 714.2 & 719.3 & 0.5819 & $709.9^{b}$ & $730.0^{a}$ & 0.0471 & 3.61 & 0.0362 \\
\hline Carcass yield, \% & 72.2 & 71.9 & 71.8 & 0.7641 & 71.77 & 72.16 & 0.4222 & 1.83 & 0.6268 \\
\hline Neck, \% & 6.97 & 7.70 & 8.10 & 0.0914 & 7.53 & 7.65 & 0.7603 & 14.54 & 0.5482 \\
\hline Breast, \% & 30.56 & 30.96 & 29.99 & 0.4106 & 30.66 & 30.34 & 0.5919 & 5.26 & 0.6977 \\
\hline Back, \% & 21.06 & 20.39 & 20.69 & 0.5898 & 20.34 & 21.09 & 0.1694 & 7.00 & 0.2298 \\
\hline Leg, \% & 29.57 & 29.78 & 30.10 & 0.4893 & 29.86 & 29.77 & 0.7942 & 3.27 & 0.3371 \\
\hline Wing, \% & 10.98 & 11.28 & 11.22 & 0.5819 & 11.40 & 10.92 & 0.0604 & 5.95 & 0.8614 \\
\hline
\end{tabular}

a-b:Means in the same row followed by different lowercase letters are significantly different $(p<0.05) ; p$ - probability; CV - coefficient of variation; D x PF - interaction between diet formulation and physical form. 
et al. (2002) mentioned that the low feed volumein the gizzard of broilers fed pelleted feeds may result in lower gizzard weight due to the lower stimulus of mechanical actions promoted by the presence of feed. Consistent results are reported in literature (Engberg et al., 2002; Lopez \& Baião, 2004), showing that gizzard relative weight of broilers fed mash diets is greater than of those fed pelleted feeds. Diet physical form significantly affected heart weight, with higher values obtained in the broilers fed the mash diets.

Total and relative abdominal fat weights were significantly influenced by diet formulation, with the diets containing PM, either as whole grain or ground, promoting higher values. As broilers fed RD and GM presented the similar numerical weight gain and feed conversion ratio values during the total experimental period, the higher abdominal fat content in the GMfed broilers was unexpected.The broilers fed WGM presented $10.5 \%$ and $17.3 \%$ heavier livers and intestines, respectively, compared with the those fed the RD diet; however, these differences were not statistically significant ( $p>0.05)$. Also the WGM- fed birds had $32.4 \%$ higher abdominal fat content ( $p>0.05)$ and $26.6 \%$ reduction in pancreas weight ( $p>0.05$ ) relative to $\mathrm{RD}$-fed broilers.

There are multiple concurrent factors related to the treatments that influenced the observed results, including Dgw, Sgw, and diet density. All exerted some degree of influence in different moments, particularly on feed intake.

\section{CONCLUSIONS}

The inclusion of $20 \%$ pearl millet in broiler diets, either as whole grain or ground, does not have negative effects on performance, carcass yield, or organ weight, independently of the feed is supplied as mash or pellets. Regardless the physical form of the feed, the inclusion of millet in the feeds increased abdominal fat deposition.

\section{REFERENCES}

Ansi/Asae. Method for determining and expressing fineness of feed materials by sieving. [ASAE Standard S319.4]. St. Joseph: American Society of Agricultural and Biological Engineers; 2008.

Table 7 - Average total (g) and relative (\%) weights of the viscera of 21-d-old broilers fed diets containing whole-grain millet (WGM), ground millet (GM), or a reference diet (RD) as mash (MASH) or pellets (PELL).

\begin{tabular}{|c|c|c|c|c|c|c|c|c|c|}
\hline \multirow{2}{*}{ Parameters } & \multicolumn{3}{|c|}{ Diets (D) } & \multirow{2}{*}{$p$ value } & \multicolumn{2}{|c|}{ Physical form (PF) } & \multirow{2}{*}{$p$ value } & \multirow{2}{*}{$\begin{array}{l}\text { CV } \\
(\%)\end{array}$} & \multirow{2}{*}{$\begin{array}{l}p \text { value } \\
D \times P F\end{array}$} \\
\hline & WGM & GM & $\mathrm{RD}$ & & MASH & PELL & & & \\
\hline Total fat, g & $18.4^{a}$ & $18.6^{a}$ & $13.9^{b}$ & 0.0249 & 16.7 & 17.3 & 0.6838 & 23.43 & 0.3620 \\
\hline Total fat, \% & $1.83^{\mathrm{a}}$ & $1.88^{\mathrm{a}}$ & $1.39^{b}$ & 0.0180 & 1.68 & 1.71 & 0.8283 & 23.19 & 0.2008 \\
\hline Gizzard, g & 27.8 & 27.6 & 26.9 & 0.6439 & $28.4^{\mathrm{a}}$ & $26.5^{b}$ & 0.0276 & 8.12 & 0.1586 \\
\hline Gizzard, \% & 2.77 & 2.78 & 2.69 & 0.6527 & $2.87^{a}$ & $2.62^{b}$ & 0.0018 & 7.51 & 0.0729 \\
\hline Intestine, g & 63.8 & 52.1 & 54.4 & 0.3026 & 57.4 & 56.1 & 0.8439 & 30.64 & 0.2999 \\
\hline Intestine, \% & 6.42 & 5.24 & 5.41 & 0.3472 & 5.84 & 5.54 & 0.6666 & 33.45 & 0.2382 \\
\hline Liver, g & 27.3 & 26.1 & 24.7 & 0.2380 & 26.5 & 25.6 & 0.4819 & 12.72 & 0.8248 \\
\hline Liver, \% & 2.72 & 2.62 & 2.47 & 0.2345 & 2.68 & 2.53 & 0.2379 & 12.42 & 0.6354 \\
\hline Heart, g & 7.20 & 7.70 & 7.20 & 0.7115 & 7.93 & 6.80 & 0.0592 & 21.06 & 0.3051 \\
\hline Heart, \% & 0.72 & 0.77 & 0.72 & 0.6467 & $0.80^{\mathrm{a}}$ & $0.67^{b}$ & 0.0273 & 20.57 & 0.3475 \\
\hline Pancreas, g & 2.35 & 3.00 & 3.20 & 0.0704 & 3.07 & 2.63 & 0.1566 & 28.29 & 0.2364 \\
\hline Pancreas, \% & 0.23 & 0.30 & 0.32 & 0.0645 & 0.31 & 0.26 & 0.1108 & 28.41 & 0.3141 \\
\hline Lung, g & 6.30 & 6.20 & 6.10 & 0.9697 & 6.07 & 6.33 & 0.6897 & 29.08 & 0.8245 \\
\hline Lung, \% & 0.63 & 0.62 & 0.61 & 0.9597 & 0.62 & 0.63 & 0.8795 & 29.16 & 0.6707 \\
\hline Spleen, g & 0.75 & 0.70 & 0.65 & 0.7011 & 0.70 & 0.70 & 1.0000 & 37.57 & 0.3572 \\
\hline Spleen, \% & 0.06 & 0.06 & 0.06 & 0.9431 & 0.06 & 0.06 & 0.9200 & 29.60 & 0.5166 \\
\hline
\end{tabular}

$a-b$ - Means in the same row followed by different lowercase letters are significantly different $(p<0.05)$; $p$ - probability; CV - coefficient of variation; D x PF - interaction between diet formulation and physical form. 
Baurhoo N, Baurhoo B, Mustafa Af, Zhao X. Comparison of corn-based and canadian pearl millet-based diets on performance, digestibility, villus morphology, and digestive microbial populations in broiler chickens. Poultry Science 2011;90(3):579-586.

Carré B. Causes for variation in digestibility of starch among feedstuffs. World's Poultry Science Journal 2044;60(1):76-89

Dahlke F, Ribeiro A, Kessler A, Lima A. Tamanho da partícula do milho e forma física da ração e seus efeitos sobre o desempenho e rendimento de carcaça de frangos de corte. Revista Brasileira de Ciência Avícola 2001;3(3):241-248

Davis AJ, Dale NM, Ferreira FJ. Pearl millet as an alternative feed ingredient in broiler diets. The Journal of Applied Poultry Research 2003;12(2):137144.

Dozier Wa, Hanna W, Behnke K. Grinding and pelleting responses of pearl millet based diets. The Journal of Applied Poultry Research 2055;14(2):269-274

Engberg RM, Hedamenn MS, Jensen BB. The influence of grinding and pelleting of feed on the microbial composition and activity in the digestive tract of broiler chickens. British Poultry Science 2002;43(4):569-79.

Flemming JS, Montanhini Neto R, Arruda JS, Franco SG, Flemming R, Souza GA. Flemming, D. F. Ração farelada com diferentes granulometrias em frangos de corte. Archives of Veterinary Science 2002;7(1):1-9.

Gomes PC, Rodrigues MP,Albino LFT, Rostagno HS, Gomes MFM, Mello HHDC, Brumano G. Determinação da composição química e energética do milheto e sua utilização em rações para frangos de corte de 1 a 21 dias de idade. Revista Brasileira de Zootecnia 2008;37(9):1617-1621.

Hadimani NA, Muralikrishna G, Tharanathan RN, Malleshi NG. Nature of carbohydrates and proteins in three pearl millet varieties varying in processing characteristics and kernel texture. Journal of Cereal Science 2001;33(1):17-25

Hidalgo MA, Davis, AJ, Dale NM, Dozier III WA. Use of whole pearl millet in broiler diets. Journal of Applied Poultry Research 2004;13(2):229-234.

Klasing KC. Comparative avian nutrition. New York: CABI Publishing; 2000.

López CAA, Baião NC. Effects of particle size and physical form of ration on performance, carcass yield and weight of digestive organs of broiler chickens. Arquivos Brasileiros deMedicina Veterinária e Zootecnia 2004;56(2):214-221.
Moran ET. Pelleting: affects feed and its consumption. Poultry Science 1987;5(1):30-37.

Murakami AE, Souza LMG de, Massuda EM, Alves FV, Holanda Guerra R de, Quiles Garcia AF. Economic evaluation and performance of broilers fed with different levels of pearl millet in substitution of corn. Acta Scientiarum. Animal Science 2009;31(1):31-37.

Nagano FH, Fernandes EA, Silveira MM, Marcacine BA, Brandeburgo JH. Efeito da peletização e extrusão da ração pré-inical sobre o desempenho final de frangos de corte. Revista Brasileira de Ciência Avícola 2003;5(2):35-42.

Netto DAM, Durães FOM. Milheto: tecnologias de produção e agronegócio Brasília: Embrapa Informação Tecnológica; Embrapa Milho e Sorgo: 2005.

Nir I, Hillel R, Ptichi I, Shefet G. Effect of particle size on performance. 3. Grinding pelleting interactions. Poultry Science 1995;74(5):771-783.

Parsons AS, Buchanan NP, Blemings KP, Wilson ME, Moritz JS. Effect of corn particle size and pellet texture on broiler performance in the growing phase. Journal of Applied Poultry Research 2006;15(2):245-255.

Passos JR HDS, Bose MLV. Uso de análise física para estimar a composição química em ingredientes para rações. Scientia Agricola 1992;49(1):159162.

Rao SVR, Raju MVLN, Reddy MR, Panda AK. Replacement of Yellow Maize with Pearl Millet (Pennisetum typhoides), Foxtail Millet (Setaria italica) or Finger Millet (Eleusine coracana) in broiler chicken diets containing supplemental enzymes. Asian-Australasian Journal of Animal Sciencesoul 2004;17(6):836-842

Rostagno HS, Albino LFT, Donzele JL, Gomes PC, Oliveira RF, Lopes DC, Ferreira AS, Barreto SLT. Tabelas brasileiras para aves e suínos: composição de alimentos e exigências nutricionais. Viçosa: UFV/DZO; 2005

Sas. Sas/Access 9.1 interface to peoplesoft: user's guide. SAS Inst. Cary: SAS Pub.; 2004

Schmidt A, Lima GJMM, Coldebella A. Método Embrapa de avaliação de peletização. São Paulo: Uniquimica; 2009. 